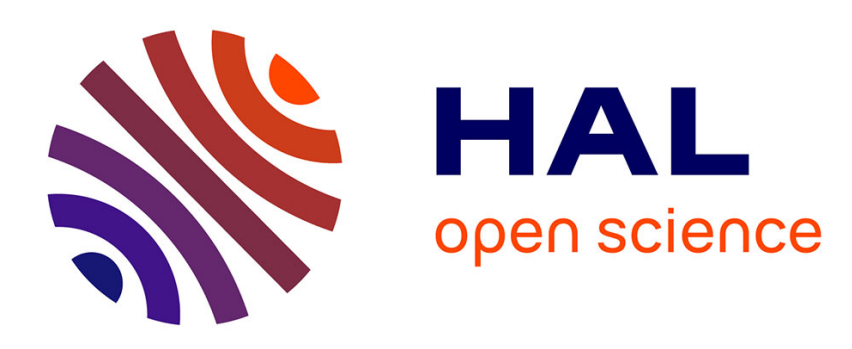

\title{
MULTILAYER SINTERING OF MnZn FERRITES IN CONTROLLED ATMOSPHERE
}

\author{
M. Alam, N. Nair, T. Ramamurti
}

\section{To cite this version:}

M. Alam, N. Nair, T. Ramamurti. MULTILAYER SINTERING OF MnZn FERRITES IN CONTROLLED ATMOSPHERE. Journal de Physique Colloques, 1977, 38 (C1), pp.C1-303-C1-309. 10.1051/jphyscol:1977163 . jpa-00217023

\section{HAL Id: jpa-00217023 https://hal.science/jpa-00217023}

Submitted on 1 Jan 1977

HAL is a multi-disciplinary open access archive for the deposit and dissemination of scientific research documents, whether they are published or not. The documents may come from teaching and research institutions in France or abroad, or from public or private research centers.
L'archive ouverte pluridisciplinaire HAL, est destinée au dépôt et à la diffusion de documents scientifiques de niveau recherche, publiés ou non, émanant des établissements d'enseignement et de recherche français ou étrangers, des laboratoires publics ou privés. 


\title{
MULTILAYER SINTERING OF MnZn FERRITES IN CONTROLLED ATMOSPHERE
}

\author{
M. I. ALAM, N. R. NAIR and T. V. RAMAMURTI \\ Central Electronics Limited, N. P. L. Campus, Hillside Road, N. Delhi, 110012, India
}

\begin{abstract}
Résumé. - Il a été mentionné dans la littérature que l'empilement de pots de ferrites les uns sur les autres durant le traitement thermique conduit à des variations notables des caractéristiques électriques dues à un effet d'ombre.Une série d'expériences a été menée au National Physical Laboratory er frittant dans un four de type production des couches multiples d'échantillons de ferrite de $\mathrm{Mn}-\mathrm{Zn}$. On a utilisé jusqu'à 10 couches d'échantillons empilés, chaque chargement comportant 3000 pots. On a mesuré toutes les caractéristiques : perméabilité, résistivité, pertes par courants de Foucauld et par hystérésis, désaccommodation et facteur de température. On n'a pas trouvé de différences notables dans les valeurs de ces facteurs en fonction de la couche concernée ; on présente les résultats expérimentaux correspondants. Des essais en production ont été effectués et ont confirmé les conclusions précédentes. On pense que la durée de stabilisation d'une heure et demie et la faible vitesse de refroidissement utilisées contribuent à l'obtention d'un équilibre qui permet aux gaz de pénétrer dans toutes les couches. Les variations des caractéristiques qui restent nettement observables apparaissent dues à des limitations inhérentes aux processus de régulation.
\end{abstract}

\begin{abstract}
It has been reported in literature that stacking of cup cores one over the other causes significant variations in electrical characteristics due to à shadow effect. At National Physical Laboratory a series of experiments were conducted on multilayer sintering of $\mathrm{MnZn}$ ferrite cores in a production type furnace. The cup cores were stacked one over the other up to ten layers. Each loading of the furnace had 3000 cup cores $18 \times 11 \mathrm{~mm}$. in size. All the electrical characteristics such as permeability, resistivity, eddy current and hysteresis loss, disaccommodation and temperature factor were measured. There was no significant difference between layers in these factors. Experimental data supporting these observations are presented. Production runs were undertaken and the experimental findings were confirmed. It is suggested that the soaking time of one and a half hour and slower cooling rate have helped to attain equilibrium conditions allowing the gases to permeate all the layers. The variation in electrical characteristics that are evident appears to be due to the inherent limitations in process control.
\end{abstract}

1. Introduction. - Slick P. L. [1] et al. (1966) in their paper titled «thermogravimetric study of solid gas interaction of $\mathrm{MnZn}$ ferrites and the effect on its magnetic properties have described an elegant experimental technique which establishes the relationship between time and temperature dependence of permeability and the amount of oxidation on cooling. Other studies have been reported, notable among which are that of Morineau et al. in 1974 [2] and 1975 [3], wherein they have presented data confirming the above findings.

Slick [1] et al. state that thermogravimetric studies can be used as a diagnostic tool to determine the relative oxygen content of ferrites fired under commercial

(*) «PADHUKA », C-61, Inder Puri, New Delhi - 110012, India. conditions. In the single example given of cup cores, stacked one over the other and fired under production like conditions, they show that the disaccommodation factor of the top core is nearly twice as large as of the bottom core. The temperature factor is not only different in value but also different in sign. The amount of oxidation of the core halves was measured with the help of the thermobalance and it was observed that the bottom core experienced less oxidation than the top core half during cooling. This is explained by the fact that the top core shields the bottom core from the furnace atmosphere.

At the National Physical Laboratory Nair [4] et al. (1970) have been studying the process parameters that determine the optimum conditions for the production of $\mathrm{MnZn}$ ferrites used by the telecommunication and television industry. The problem posed was 
how to utilise the full capacity of the box type controlled atmosphere furnace to get maximum yields. It was decided to study the shadow effect reported, by carrying out a series of experiments on multilayering of cup core halves and to see how best they can be fired to minimise the shadow effect, and get cores which are within acceptable limits.

2. Experimental. - The controlled atmosphere box furnace and the associated equipment for controlling and metering the flow of oxygen and inert gas are described in detail by Alam [5] et al. (1974). The same furnace with its associated controls was used for the experiments. The furnace can accommodate four sillimanite plates, of $254 \times 203 \mathrm{~mm}$. Each plate can hold about 100,18 $\times 11 \mathrm{~mm}$ pot cores in single layer. The experiments consisted of stacking them in four, six and ten layers. By stacking them one over the other in layers a very large number of pot core halves are subjected to the shadow effect. The test results on these cores will indicate the changes in material characteristics due to oxidation/reduction. The pot cores have two slots diametrically opposite to each other, and $3.8 \mathrm{~mm}$ wide. The slots extend to the full height of the core halves. Some were stacks with slots staggered. Plate 1 carried four layers, No. 2 six layers and the 3 rd plate ten layers. The effective volume of each pot core half was $0.56 \mathrm{~cm}^{3}$ while the total exposed surface area was $10.2 \mathrm{~cm}^{2}$. Firing conditions for the chosen composition were $1340^{\circ} \mathrm{C} \pm 5^{\circ} \mathrm{C}$. Soaking time was 90 minutes. Inert gas (argon) flow during soaking was 15 litres per minute with an oxygen content of 0.75 litre i. e. about $5 \%$. Flow during cooling cycle was 8 litres of inert gas only, with the oxygen totally cut off. Inert gas flow was maintained till the furnace cooled to $500^{\circ} \mathrm{C}$.

The plates were taken out after the furnace had cooled down below $100^{\circ} \mathrm{C}$. Core halves were allowed to cool to room temperature, lapped and demagnetised. They were toroidally wound and the magnetic characteristics were tested. About 10 percent of the core halves randomly chosen, were selected for detailed measurements of D. F. and T. F. Results are plotted in the form of Histograms (Figs. 2 to 4). Microstructures of

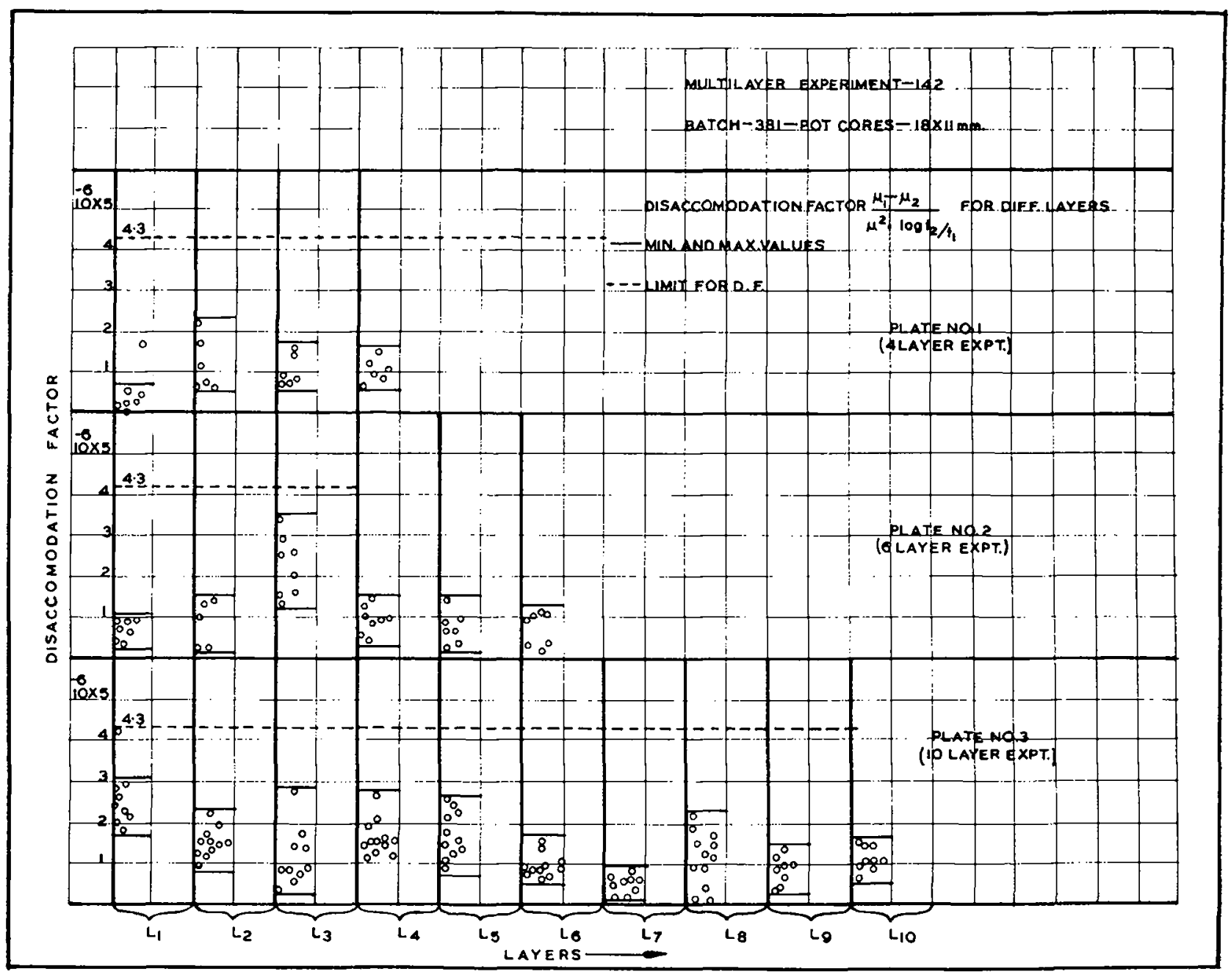

Fig. 1. 


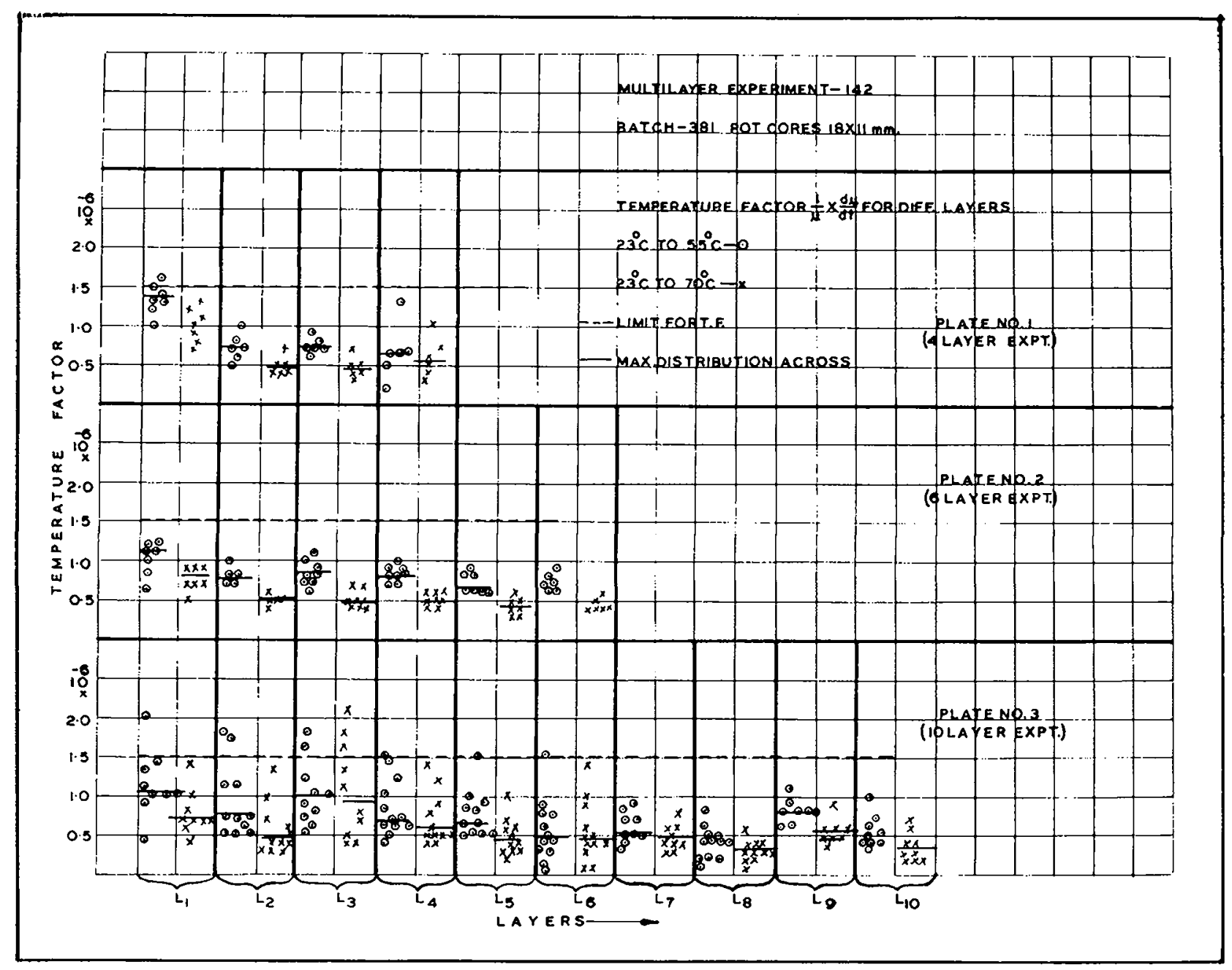

Fig. 2.

randomly chosen core halves from bottom, middle and top are presented in figures 5, 6 and 7 .

3. Discussion. - 3.1 Disaccommodation and temPERATURE FACTOR. - Histograms (Figs. 1 and 2) give the results of experiments with 4,6 and 10 layers of core halves for these two parameters. In most cases the values are close clusters for any layer except one or two deviations; but these are unrelated. There does not appear to be any discernible pattern which is systematic and can be attributed to shielding of lower by upper cores.

Mossman [6] (1967) has shown that permeability and hysteresis losses are very sensitive to reduction/ oxidation mechanism in $\mathrm{MnZn}$ ferrites during the cooling phase. The measured values of permeability, resistivity, hysteresis and residual losses on the same cores are presented in figure 3 and 4. Mossman's curves of permeability and losses show a very sharp peak and there is an optimum for the rate flow of inert gas. This was also our finding (Alam [5] et al.). The disaccommodation factor, while sensitive to cooling rate below the optimum, levels off as the flow is increased. Values of permeability, resistivity and losses form a close cluster in all the experiments and in different layers. This is possible only if the inert gas with the appropriate amount of oxygen, permeates uniformly tbroughout the whole furnace and between layers and the oxidation/reduction takes place freely to achieve stoichiometry of the chosen composition in all cores. It is still more important to ensure that the rate of decay of oxygen content during the cooling phase follows the universal equilibrium curve first postulated by Blanck [7] (1965) for MnZn ferrites. This is ensured by maintaing an 8 litres per minute flow of inert gas during the cooling phase. This has been found to be optimum for this box furnace with its rate of cooling characteristic. 


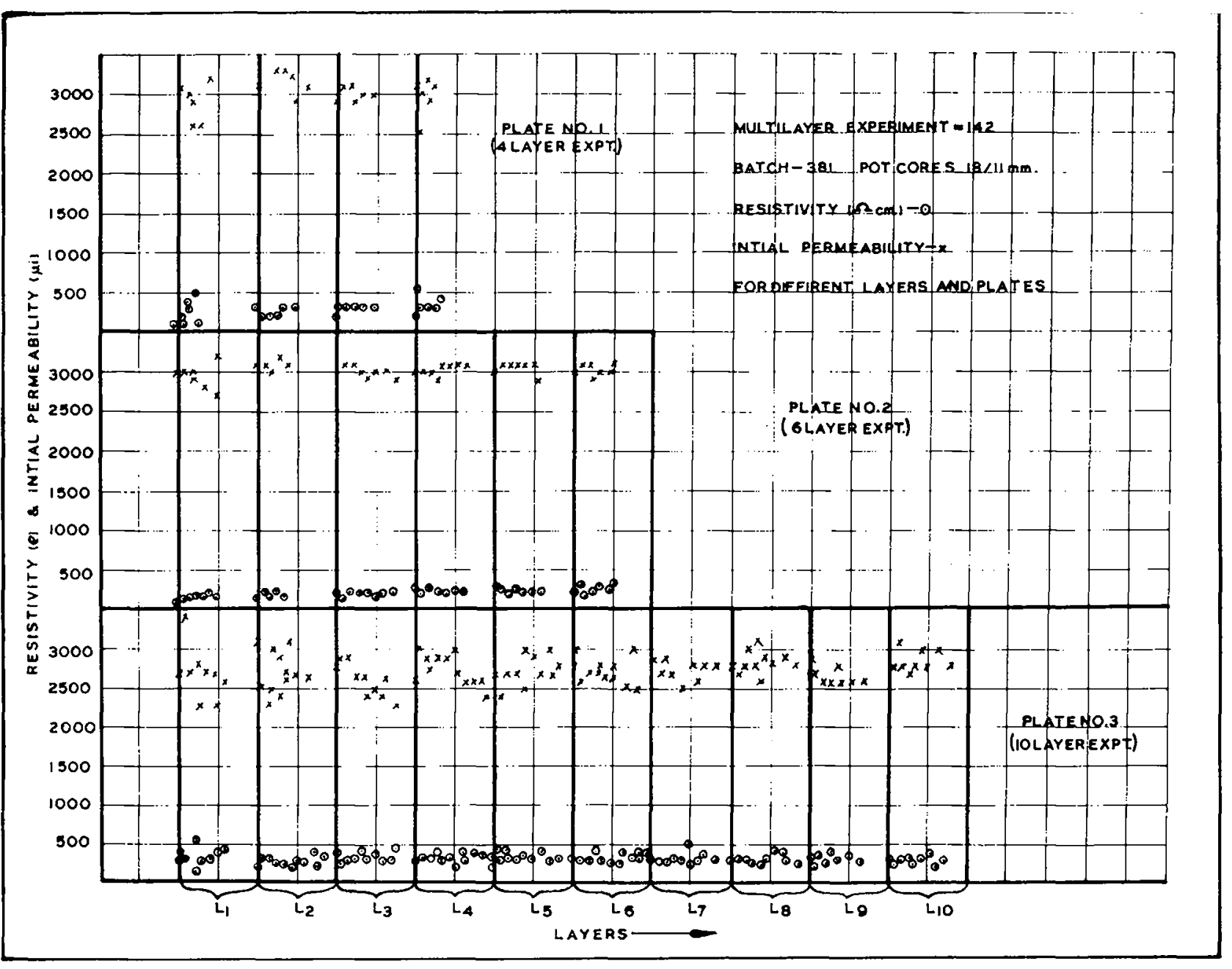

FIG. 3.

The results presented of all the experiments confirm the finding that the distribution of characteristics among the different layers of cup cores is quite random and no shielding effect is evident of the bottom core by the top core in successive layers. Results of a single layer firing (Table I) also follow the same randomness in distribution of characteristics. The variation between cores whether in multilayer or single layer, appears to be due to the limitations inherent in processing $\mathrm{MnZn}$ ferrite cup cores in large numbers.

The photo micrographs (Figs. 5, 6 and 7) of cup cores drawn from bottom, middle and top layers show the same uniformity in the grains and size. Alam [8] (1975) et al. have shown that if during soaking there is paucity of oxygen uniform grain growth is inhibited. Hence it appears that stacking of the cores have not affected the permeation of the oxygen carrying inert gas to all layers.

The specification laid down for telecommunication ferrites are given in table II. It could be observed that the values attained in the multilayer firing experiments are well within limits prescribed in the specifications. Hence it was felt that the same procedure of stacking the cup cores to utilise fully the box furnace capacity may safely be adopted for production purposes.

Consequently Central Electronics Limited, a manufacturing organisation for professional grade of ferrites, commenced production using the same box furnace. The core size chosen was $26 \times 16 \mathrm{~mm}$. The core halves have an effective volume of $1.77 \mathrm{~cm}^{3}$ and exposed surface area of $21 \mathrm{~cm}^{2}$. Core halves stacked to five layers were loaded into the furnace, the total number per firing being of the order of 860 core halves.

Table III gives the results fo some typical firing. As can be seen the characteristics fall within the specification limits in most cases. Firing No. P-159 and 151 show a slight shift in temperature coefficient to lower limits. This can be corrected by adjustement of soaking temperature and atmosphere. 


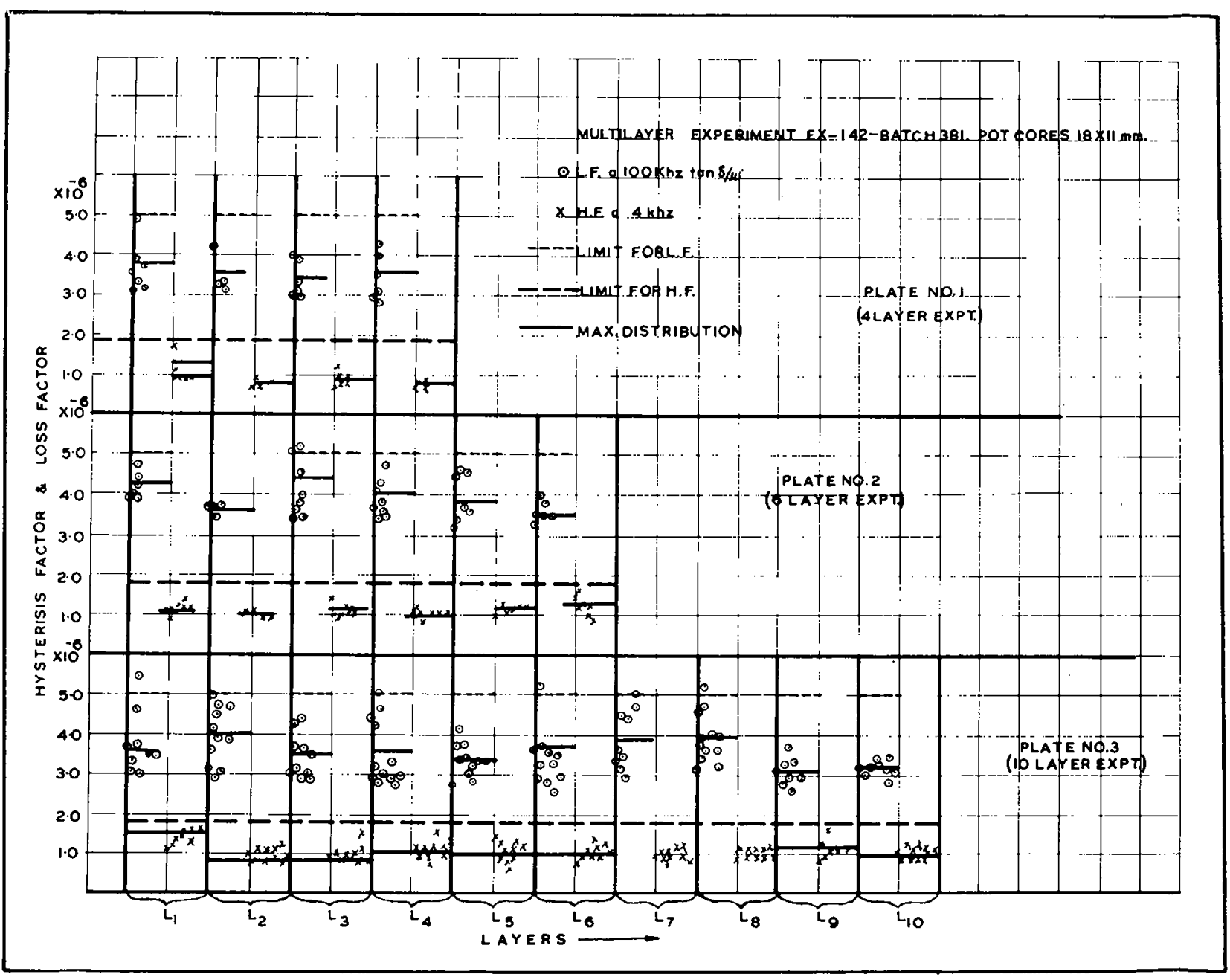

Fig. 4.

TABLE I

Results of single layer firing

$\begin{array}{ccccccc}\text { Sample } & \begin{array}{c}\text { Specific D. C. } \\ \text { resistance }\end{array} & \begin{array}{c}\text { Initial } \\ \text { permeability } \\ @\end{array} & \begin{array}{c}\text { Disaccommodation } \\ \text { factor @ } \\ 23 \pm 1{ }^{\circ} \mathrm{C}\end{array} & \begin{array}{c}\text { Hysteresis } \\ \text { coefficient }\end{array} & \begin{array}{c}\text { Loss factor } \\ \text { at } \\ 100^{\mathrm{kHz}}\end{array} & \begin{array}{c}\text { Temperature } \\ \text { factor } \\ 23-70^{\circ} \mathrm{C}\end{array} \\ \text { No. } & \text { Ohm-cm } & 4 \mathrm{kHz} \mu_{\mathrm{i}} & \begin{array}{c}\text { D. F. } \times 10^{-6} \\ \eta_{\mathrm{B}} \times \frac{10^{-6}}{\mathrm{mT}}\end{array} & \times 10^{-6} & \times 10^{-6} \\ - & - & - & - & - & - & - \\ 1 & 730-830 & 1929 & 4.2 & 0.86 & 4.0 & 1.5 \\ 2 & 650-660 & 1903 & 4.6 & 0.74 & 4.1 & 1.3 \\ 3 & 520-650 & 2112 & 3.7 & 0.74 & 4.3 & 1.3 \\ 4 & 400-420 & 2507 & 3.2 & 0.62 & 3.4 & 1.0 \\ 5 & 430-480 & 2592 & 3.2 & 0.68 & 4.1 & 1.2 \\ 6 & 340-500 & 2362 & 2.2 & 0.62 & 4.2 & 1.0 \\ 7 & 450-460 & 2383 & 3.4 & 0.62 & 5.4 & 1.2 \\ 8 & 290-300 & 2574 & 2.4 & 0.80 & 5.2 & 0.9 \\ 9 & 280-300 & 2494 & 2.9 & 1.08 & 3.7 & 1.0 \\ \text { Mean } & 480 & 2033 & 3.3 & 0.85 & 4.3 & 1.16 \\ \text { value } & & & & & & \end{array}$




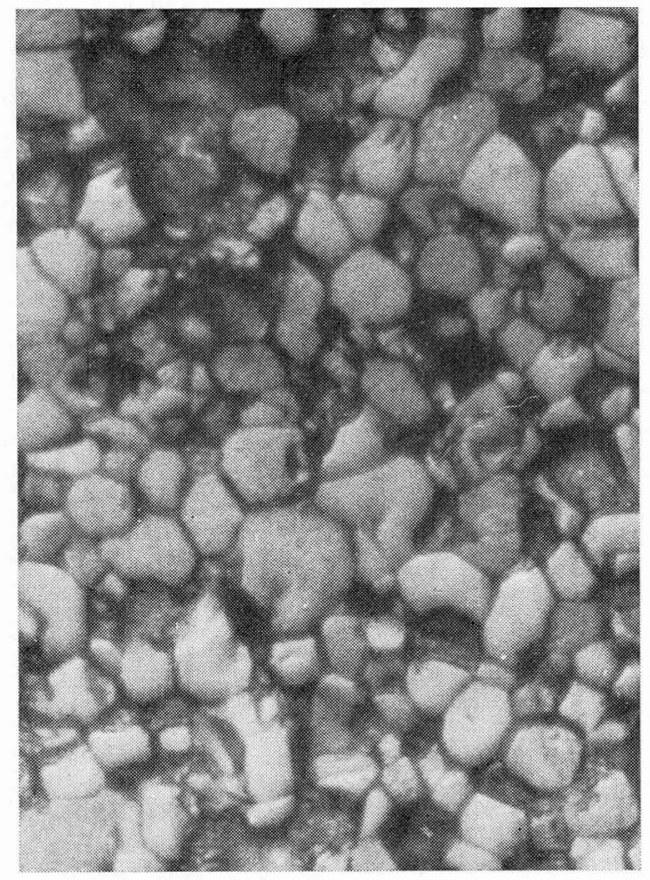

FIG. 5. - Microphoto of 1st layer cup core.

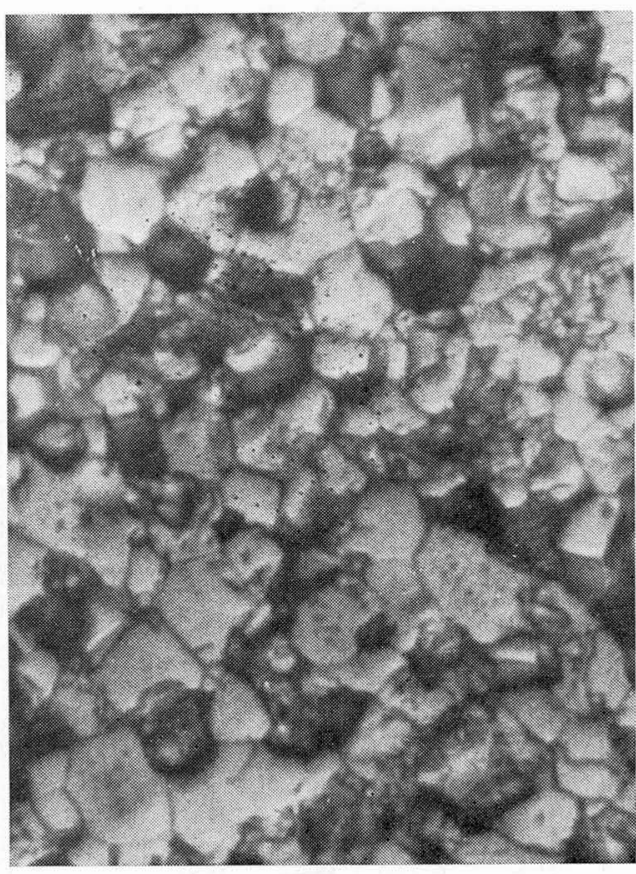

FIG. 6. - Microphoto of 4th layer cup core.

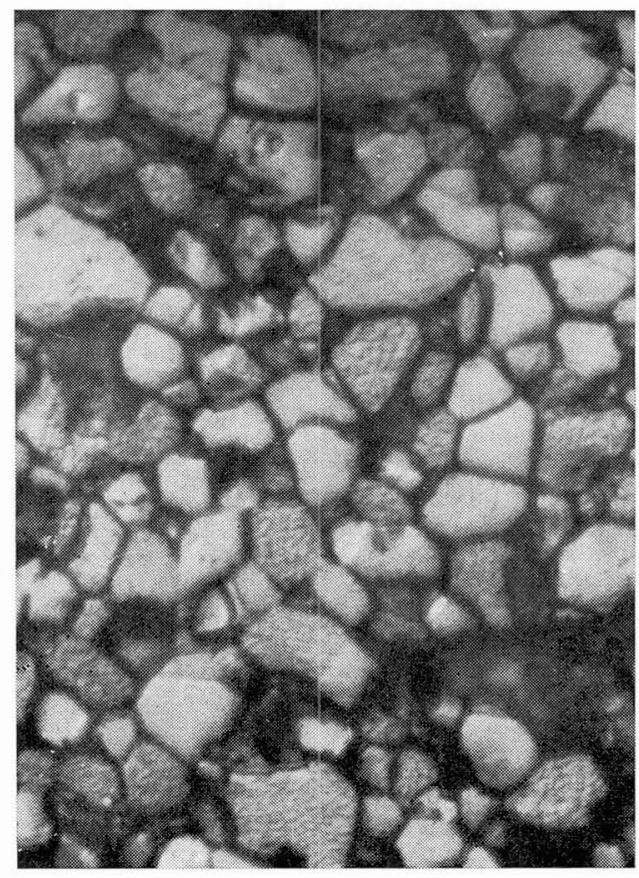

FIG. 7. - Microphoto of 9th layer cup core. 
TABLE II

Material properties of cup cores

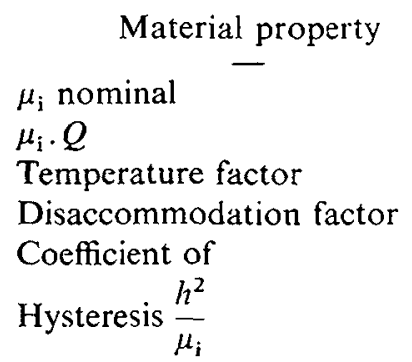

$\begin{array}{cc}\text { Batch } & \text { Firing } \\ \text { No. } & \text { No. } \\ \overline{434} & \text { P-122 } \\ 449 & \text { P-151 } \\ 449 & \text { P-154 } \\ 458 & \text { P-159 }\end{array}$

Standard conditions for measurement

$\begin{array}{rrc}23^{\circ} \mathrm{C} & 100 \mathrm{kHz} & 5 \text { gauss } \\ 23^{\circ} \mathrm{C} & 100 \mathrm{kHz} & 5 \text { gauss } \\ 23-70^{\circ} \mathrm{C} & 1 \mathrm{kHz} & \\ 23^{\circ} \mathrm{C} & 1 \mathrm{kHz} & 10 \text { and } 100 \mathrm{~min} . \\ 23^{\circ} \mathrm{C} & & 5 \text { to } 25 \text { gauss }\end{array}$

TABLE III

Properties of cup cores pairs in production

No. of core
pairs
$\overline{159}$
132
305
115

$$
\begin{aligned}
& \begin{array}{l}
\text { Range of } \\
\text { D. F. }
\end{array} \\
& \text { 0.03-1.1 } \\
& \begin{array}{lll}
0.3 & -1.4
\end{array} \\
& 0.3-3.5 \\
& \begin{array}{lll}
0.9 & -3.6
\end{array}
\end{aligned}
$$

4. Conclusions. - 1. Stacking of cup cores one uver the other does not adversely affect the proper sintering of the cup cores and achieving the desired stoichiometric composition. 2. It is possible to utilise the full capacity of the box furnace thus achieving economics of production. 3.60 to $80 \%$ of the sintered cup cores fall within the specification limits.

The first two of the authors are now with the Central Electronics Ltd. and are utilising their riche experience in the laboratory to carry out modest production of professional grade $\mathrm{MnZn}$ ferrites.

Thanks are due to Central Electronics for agreeing to permit the publishing of the production results and to National Physical Laboratory for the experimental results.

The authors are grateful to Dr. R. Krishnan an erst while colleague of theirs who has kindly agreed to present the paper on their behalf.

\section{References}

[1] Slick, P. L. and Bfsseches, H., I. E. E. E. Trans. Mag. 2 (1966) 603.

[2] Morineau, R. and Paulus, M., Phys. Stat. Sol. (a) 20 (1973) 373.

[3] Morineau, R. and Paulus, M., I. E.E. Trans Mag-11 5 (1975) 1312.

[4] Nair, N. R., Khanduja, R. S., Ramamurti, T. V., Proc. Symp. Mat. Sci. Res. D. A, E. 1 (1970) 400.
[5] Alam, M. I., Nair, N. R., Sharma, C. D., Ramamurti, T. V., Res \& Ind. 194 (1974) 139.

[6] Mossman, P., Mag. Mat. and their applications. (Conf. Pub. I. E. E.) 33 (1967) 164.

[7] Blank, J. M., J. Appl. Phys. 36 (1965) 1022.

[8] Alam, M. I., Shambavidevi Rao, Ramadevi Ramchandran, NaIr, N. R., Ramamurti, T. V., Proc. Ind. Acad. Sci. 82A 3 (1975) 88. 